\title{
Photosynthesis and inorganic carbon utilization in Pleurochrysis sp. (Haptophyta), a coccolithophorid alga
}

\author{
Alvaro A. Israel ${ }^{*}$, Elma L. González** \\ Department of Biology, University of California Los Angeles, Los Angeles, California 90095-1606, USA
}

\begin{abstract}
We studied and compared properties of inorganic carbon fixation for 2 coccolithophorid strains that differ in their capacity to calcify; namely high calcifying (HC) Pleurochrysis sp. CCMP 299 and low calcifying (LC) Pleurochrysis elongata CCAP 961/3. Pleurochrysis species are unicellular algae that, in nature and in culture, produce intracellular $\mathrm{CaCO}_{3}$ encrusted structures (coccoliths). Pleurochrysis, and other calcifying algae, are potential players in atmospheric $\mathrm{CO}_{2}$ cycling and the maintenance of global carbon balances. In Pleurochrysis sp. and $P$. elongata (hereafter Pleurochrysis), photosynthesis was affected by increasing $\mathrm{O}_{2}$ (from 1 to $21 \%$ in air), with $18 \%$ inhibition for LC cells and $9 \%$ for $\mathrm{HC}$ cells. The inhibition could be reversed by (1) decreasing the ambient $\mathrm{O}_{2},(2)$ reducing the ambient $\mathrm{pH}$ (which rose in the medium, particularly for LC cells) and (3) by increasing the ambient inorganic carbon concentration. Carbonic anhydrase activity was detected in Pleurochrysis; HC cells having approximately 4 times more activity than LC cells. Inhibition of carbonic anhydrase by $0.25 \mathrm{mM}$ acetazolamide (a non-membrane-permeating inhibitor of the enzyme) averaged $30 \%$ in $\mathrm{HC}$ cells and only $10 \%$ in LC cells. Calcium uptake measured for $\mathrm{HC}$ cells was 2.5 to 3.0 times higher in the light and 4 times higher in the dark than calcium uptake measured for LC cells. Rates of photosynthetic $\mathrm{O}_{2}$ evolution were significantly higher for both strains at acidic $\mathrm{pH}$ (e.g. 5.0, containing about $90 \% \mathrm{CO}_{2}$ ) than at seawater $\mathrm{pH}$ (e.g. 8.0, having about $1 \% \mathrm{CO}_{2}$ ), while at a basic $\mathrm{pH}$ (e.g. 9.0, virtually no $\mathrm{CO}_{2}$ and about $50 \% \mathrm{HCO}_{3}{ }^{-}$) rates were still substantial for $\mathrm{HC}$ cells but extremely low for LC cells. These data indicate that $\mathrm{HC}$ cells in their natural environment are primarily $\mathrm{HCO}_{3}{ }^{-}$users. By comparing seawater $\mathrm{CO}_{2}$ concentrations (i.e. $\left.15 \mu \mathrm{M}\right)$ with calculated $K_{0.5}\left(\mathrm{CO}_{2}\right)$, the $\mathrm{CO}_{2}$ concentration required for a halfmaximal rate of photosynthetic $\mathrm{O}_{2}$ evolution, for Pleurochrysis (51 and $37 \mu \mathrm{M}$ for $\mathrm{HC}$ and LC cells, respectively) it follows that $\mathrm{CO}_{2}$ must be concentrated intracellularly for effective photosynthesis in both strains. Thus, an adequate $\mathrm{CO}_{2}$ supply depends on $\mathrm{HCO}_{3}{ }^{-}$utilization and concomitant calcification, particularly in HC cells.
\end{abstract}

KEY WORDS: Calcium uptake - Carbon utilization - Coccolithophorid P Photosynthesis - Rubisco

\section{INTRODUCTION}

Among the unicellular marine algae, coccolithophorids (Haptophyceae) are a widespread group of phytoplankters with distinct scales or plates of $\mathrm{CaCO}_{3}$ (coccoliths) that, either partially or entirely, cover the cell in a loosely organized layer. Coccolithophorid algae

\footnotetext{
- Present address: Israel Oceanographic \& Limnological Researrh I.td, Natinnal Institute of Oceanography, Tel Shilk mona, POB 8030, Haifa 31080, Israel

- Addressee for correspondence.

E-mail: gonzalez@biology.lifesci.ucla.edu
}

remove large quantities of atmospheric $\mathrm{CO}_{2}$ through photosynthesis and calcification and are, therefore, an important component of the global carbon cycle (Raven 1991, McConnaughey 1994), accounting for a substantial part of the ocean floor limestone sediments.

Inorganic carbon $\left(\mathrm{C}_{\mathrm{i}}\right)$ dissolved in seawater is mostly composed of high levels of $\mathrm{HCO}_{3}^{-}$(ca $2100 \mu \mathrm{M}$ ) and low concentrations of $\mathrm{CO}_{2}$ (ca $\left.15 \mu \mathrm{M}\right)$. Thus, not surprisingly, most of the microalgae (Dixon et al. 1987 , Munoz \& Merrett 1989) as well as the macroalqae (Beer 1994) are able to utilize $\mathrm{HCO}_{3}{ }^{-}$as the exogenous $\mathrm{C}_{\mathrm{i}}$ source for photosynthesis. Some microalgae can translocate $\mathrm{HCO}_{3}{ }^{-}$across the plasmalemma for intra- 
cellular conversion to $\mathrm{CO}_{2}$ (Dixon et al, 1987), while others convert $\mathrm{HCO}_{3}^{-}$to $\mathrm{CO}_{2}$ extracellularly with $\mathrm{CO}_{2}$ readily diffusing into the cell (Badger et al. 1980). A few algae rely on diffusive entry or active uptake of $\mathrm{CO}_{2}$ (Raven 1991, Badger 1985). The $\mathrm{C}_{1}$ is thus concentrated intracellularly, enhancing the levels of $\mathrm{CO}_{2}$ at the site of fixation via ribulose 1,5-bisphosphate carboxylase/oxygenase (Rubisco). Carbonic anhydrase (CA) is associated with one of these 'biophysical $\mathrm{C}_{L^{-}}$ concentrating mechanisms' since it catalyzes the reversible hydration of $\mathrm{CO}_{2}\left(\mathrm{H}^{+}+\mathrm{HCO}_{3}^{-} \rightleftharpoons \mathrm{H}_{2} \mathrm{CO}_{3}\right.$ $\rightleftharpoons \mathrm{H}_{2} \mathrm{O}+\mathrm{CO}_{2}$ ). This enzyme is localized in the chloroplast stroma and/or bound to the plasmalemma (Moroney et al. 1985).

Studies on transport and fixation of $\mathrm{C}_{1}$ have largely focused on green microalgae and cyanobacteria. Among the coccolithophorid microalgae, Emiliania huxleyi has received the most attention because of its ecological importance in marine environments. Despite its putative role in the global carbon cycle, E. huxleyi is apparently limited by the $\mathrm{CO}_{2}$ concentrations of seawater (Sikes et al. 1980, Nimer et al. 1992). Furthermore, it is known that $E$. huxleyi utilizes $\mathrm{HCO}_{3}{ }^{-}$for calcification and photosynthesis, although a low calcifying strain has shown poor affinity for $\mathrm{HCO}_{3}{ }^{-}$and preferentially uses $\mathrm{CO}_{2}$ (Nimer \& Merrett 1992, Sekino \& Shiraiwa 1994).

If bicarbonate is a source of $\mathrm{CO}_{2}$ for carbon fixation, it is also, simultaneously, a source of carbonate for mineralization (calcification) (see McConnaughey 1994). Apparently, the calcification reactions are important for sustaining high rates of photosynthesis in calcifying cells (Nimer \& Merrett 1992, 1993). Conversely, if $\mathrm{CO}_{2}$ is taken in across the plasmalemma, the acidotic calcification reactions may not be necessary for sustaining photosynthesis. Current models for $\mathrm{C}_{\mathrm{i}}$ acquisition in the coccolithophorid algae do not take into consideration a potential extracellular location of CA. Instead, they primarily focus on an internally localized (i.e. chloroplast) enzyme to boost $\mathrm{HCO}_{3}{ }^{-} \rightarrow \mathrm{CO}_{2}$ rates (Sikes \& Wheeler 1982, Quiroga \& González 1993).

The present investigation compares 2 strains of Pleurochrysis differing in their calcification capacity. The relationships among $C_{i}$ utilization, carbonic anhydrase, calcification and photosynthesis are explored. Ultrastructural (Brown \& Romanovicz 1976) and cellular studies of calcification (Kwon \& González 1994) have been conducted on Pleurochrysis, but no previous physiological work has been done to elucidate its mechanism of $\mathrm{C}_{\mathrm{i}}$ utilization.

\section{MATERIALS AND METHODS}

Algae and growth conditions. A high calcifying (HC) strain of Pleurochrysis sp. (CCMP299, Center for
Culture of Marine Phytoplankton, Bigelow Laboratory, Maine) and a low calcifying (LC) Pleurochrysis elongata (CCAP961/3. Culture Collection of Algae and Protozoa, Scotland) were grown axenically at $15^{\circ} \mathrm{C}$ and pH 7.5 as described previously (Wainwright et al. 1992). Cultures used in subsequent experiments were harvested at 5 wk (Quiroga \& González 1993). The 2 strains used in this study are hereafter called Pleurochrysis.

Measurements of net photosynthesis. Photosynthetic $\mathrm{O}_{2}$ evolution was measured from $4.0 \mathrm{ml}$ cell suspensions (averaging $4.7 \pm 0.8 \times 10^{5}$ cell ml ${ }^{-1}, \mathrm{n}=5 \pm \mathrm{SD}$ ) with an $\mathrm{O}_{2}$ electrode, liquid phase system (Hansatek Ltd, Kings Lynn, Norfolk, UK), set at $15^{\circ} \mathrm{C}$ and attached to a chart recorder. Usually, just before measurements were started, $\mathrm{O}_{2}$ in the cell suspension was reduced to desired levels by gentle bubbling with $\mathrm{N}_{2}$ for up to $30 \mathrm{~s}$. Cells were allowed to photosynthesize under saturating photosynthetic photon flux (PPF) of 500 umol $\mathrm{m}^{-2} \mathrm{~s}^{-1}$, PAR was provided by halogen lamps until rates of $\mathrm{O}_{2}$ evolution were steady. Saturating PPF was established from measurements of net photosynthesis at various PPF levels created with neutral density glass filters.

$\mathrm{pH}$ effects on photosynthesis. The response of photosynthetic $\mathrm{O}_{2}$ evolution to changes in the ambient (extracellular) $\mathrm{pH}$ was determined in $10 \mathrm{mM}$ biological buffer (Sigma). A stock solution of MES (pH 5.0 and 6.0), Bis-TRIS ( $\mathrm{pH} 6.5$ ), HEPES ( $\mathrm{pH} 7.0$ and 7.5), TRIS$\mathrm{HCl}(\mathrm{pH}$ 8.0) or CAPS (pH 9.0) was injected into a cell suspension in $2 \mathrm{mM}$ inorganic carbon $\left(\mathrm{C}_{\mathrm{i}}\right)$ in the $\mathrm{O}_{2}$ electrode chamber Measurements were continued until stable rates of photosynthesis were recorded.

Photosynthesis under carbon limitation. $\mathrm{CO}_{2}$ depleted cell suspensions were prepared as follows: a $30 \mathrm{ml}$ culture sample was allowed to stand for $45 \mathrm{~min}$ at saturating PPF until the cells settled to the bottom of sterile plastic tubes. Cells were then retrieved with a pipette and resuspended in a $\mathrm{CO}_{2}$-free artificial seawater medium $(450 \mathrm{mM} \mathrm{NaCl}, 10 \mathrm{mM} \mathrm{CaCl}, 10 \mathrm{mM}$ $\mathrm{KCl}$ and $30 \mathrm{mM} \mathrm{MgSO}_{4}$ ) for an additional 30 min under illumination. This technique for cell collection was preferred because centrifugation apparently reduced the photosynthetic capacity of Pleurochrysis. $\mathrm{C}_{\mathrm{i}}$-dependent $\mathrm{O}_{2}$ evolution was measured after $\mathrm{NaHCO}_{3}$ (from freshly prepared stock solutions) was added to cells suspended in $\mathrm{CO}_{2}$-free artificial seawater medium. The bicarbonate-free $\mathrm{O}_{2}$ electrode system was closed, and the $\mathrm{pH}$ was set at 5.5 with MES, 7.5 with HEPES, or 8.5 with TRIS-HCl. After a stable baseline was attained, aliquots of the $\mathrm{NaHCO}_{3}$ stock solution were injected into the electrode chamber to generate a range of $C_{1}$ concentrations. To prepare cells for measurements at low $\mathrm{pH}$, the samples from both strains were treated with $1 \mathrm{~N} \mathrm{HCl}$ and stirred for 3 to $4 \mathrm{~min}$. 
After $\mathrm{HCl}$ treatment, $\mathrm{pH}$ was adjusted and $\mathrm{C}_{\mathrm{i}}$ added. This treatment effectively removes external, coccolith $\mathrm{CaCO}_{3}$.

Changes in the ambient $\mathrm{pH}$ were measured directly with a $\mathrm{pH}$ electrode in the $3 \mathrm{ml}$ cell suspension contained in the electrode glass chamber. To keep a gas-tight system, the tip of the $\mathrm{pH}$ electrode was fitted with a rubber O-ring to seal off the opening of the glass chamber. Next, the light was turned on and changes in $\mathrm{pH}$ and $\mathrm{O}_{2}$ evolution were recorded simultaneously over 20 to 30 min periods. Rates of net photosynthesis were followed as $\mathrm{O}_{2}$ increased in the chamber from about 2 to $30 \%$. In other experiments, the $\mathrm{pH}$ of the medium was decreased to 6.0 with $10 \mathrm{mMMES}$ buffer, when the concentration of $\mathrm{O}_{2}$ reached $280 \mu \mathrm{M}(25 \%$ in air) or, alternatively, the $\mathrm{C}_{1}$ in the medium was increased by additions of $2 \mathrm{mM} \mathrm{HCO}_{3}{ }^{-}$; and photosynthetic rates were again recorded.

Carbonic anhydrase. The activity of extracellular CA of intact cells was estimated by measuring the time-course of $\mathrm{pH}$ decrease (from 8.0 to 6.5) with a $\mathrm{pH}$ meter (Autex 4500, Beckman, Fullerton, CA) connected to a chart-recorder. When the $\mathrm{pH}$ of a mixture consisting of $4 \mathrm{ml}$ cell suspension and $1 \mathrm{ml} 5 \mathrm{mM}$ TRIS$\mathrm{HCl}$ buffer solution at $4^{\circ} \mathrm{C}$ had stabilized at $8.2,0.5 \mathrm{ml}$ $\mathrm{CO}_{2}$-saturated distilled water was added and the decrease in $\mathrm{pH}$ was recorded. Blanks were prepared by mixing $1 \mathrm{ml}$ buffer solution with $4 \mathrm{ml}$ seawater medium, or boiled cell suspensions prior to the addition of the $\mathrm{CO}_{2}$-saturated distilled water. The effect of acetazolamide (AZ), a non-membrane-permeating inhibitor, on CA was determined. Increasing amounts of the inhibitor were added to the cell-buffer mixture immediately before the hydration reaction was initiated with $\mathrm{CO}_{2}$

Calcium uptake. Rates of calcium sequestration by cells of Pleurochrysis were determined by means of a colorimetric method (Pethig et al. 1989). $\mathrm{Ca}^{2+}$ ions were assayed by a chromogenic calcium chelator, 5, 5'-dinitro BAPTA free acid (BAPTA, Molecular Probes, Inc., Eugene, OR), in the cell medium at the beginning and end of timed incubations. A cell suspension (4 $\mathrm{ml}_{i}$ containing $9.1 \pm 1.2 \mathrm{mM} \mathrm{Ca}^{2+}, \mathrm{n}=5 \pm \mathrm{SD}$ ) was incubated at $15^{\circ} \mathrm{C}$ for 1.5 to $2.0 \mathrm{~h}$ (in $5 \mathrm{ml}$ glass chambers open to the atmosphere and occasionally bubbled with $\mathrm{N}_{2}$ to avoid $\mathrm{O}_{2}$ build up) at fluxes of $500,75 \mu \mathrm{mol} \mathrm{m} \mathrm{m}^{-2} \mathrm{~s}^{-1}$ or darkness. Then, $1.0 \mathrm{ml}$ of the cell suspension was withdrawn, centrifuged at $13000 \times g$ for $3 \mathrm{~min}$ and the supernatant mixed with $20 \mu \mathrm{l}$ of a $1.0 \mathrm{mM}$ BAPTA solution. After $5 \mathrm{~min}$ the color was measured at $426 \mathrm{~nm}$ in a spectrophotometer (Beckman 25, Beckman). Concentrations were calculated using regression equations derived from $\mathrm{CaCl}_{2}$ calibration curves.

Other methods and calculations. Cell number per ml of culture was determined with a hemocytometer.
Chlorophyll a was extracted and measured according to Moran (1982); cells were collected by centrifugation from $1.0 \mathrm{ml}$ cell suspensions and immersed in $1.0 \mathrm{ml}$ $\mathrm{N}, \mathrm{N}$-dimethylformamide at $4^{\circ} \mathrm{C}$ in the dark for $24 \mathrm{~h}$. The extracts were read at 663 and $647 \mathrm{~nm}$ with the spectrophotometer. Rates of non-enzymatic dehydration of $\mathrm{HCO}_{3}{ }^{-}$to form $\mathrm{CO}_{2}\left(d \mathrm{CO}_{2} / d \mathrm{t}\right)$ were calculated according to Johnson (1982). PPF was measured with a LI-193S quantum sensor (LI-COR, Lincoln, NE). Statistical significance of results was determined by Student's t-test.

\section{RESULTS}

Low calcifying cells and high calcifying cells required similar PPF to achieve maximal rates of photosynthetic $\mathrm{O}_{2}$ evolution, both about $200 \mu \mathrm{mol} \mathrm{m} \mathrm{m}^{-2} \mathrm{~s}^{-1}$ (Fig. 1). At $50 \mu \mathrm{mol} \mathrm{m} \mathrm{m}^{-1}$ (i.e. subsaturating PPF) the initial slope of the photosynthetic reaction was steeper and net photosynthesis averaged $34 \%$ higher levels for $\mathrm{HC}$ cells than for LC cells ( $\mathrm{p}<0.01$; Fig. 1). At $500 \mu \mathrm{mol}$ $\mathrm{m}^{-2} \mathrm{~s}^{-1}$ (i.e. saturating PPF) net photosynthesis in LC cells averaged $13 \%$ higher $(p<0.05)$ than net photosynthesis in $\mathrm{HC}$ cells. At the ambient PPF for culture growth in the laboratory $\left(75 \mu \mathrm{mol} \mathrm{m} \mathrm{m}^{-2} \mathrm{~s}^{-1}\right)$ the content of chlorophyll a was $20 \%$ higher in LC cells compared to $\mathrm{HC}$ cells $\left(0.47 \pm 0.02 \mu \mathrm{g}\right.$ chl a $10^{6} \mathrm{cells}^{-1}$ vs $0.39 \pm$ $0.03 \mu \mathrm{g} \mathrm{chl} \mathrm{a} 10^{6}$ cells $^{-1}, \mathrm{n}=8 \pm \mathrm{SD}$ ).

At ambient levels of $\mathrm{O}_{2}(21 \%$ in air corresponding to $227 \mu \mathrm{M} \mathrm{O}_{2}$ at $15^{\circ} \mathrm{C}$ ), the rates of net photosynthesis at $\mathrm{pH} 7.5$ were $82 \%(\mathrm{p}<0.05)$ for LC cells and $91 \%(\mathrm{p}<$ $0.05)$ for $\mathrm{HC}$ cells when compared to the rates of net photosynthesis attained at $2 \% \quad \mathrm{O}_{2} \quad \begin{array}{llll}21.3 & \mu \mathrm{M} & \mathrm{O}_{2}\end{array}$ Table 1). When $\mathrm{O}_{2}$ concentrations averaging $230 \mu \mathrm{M}$

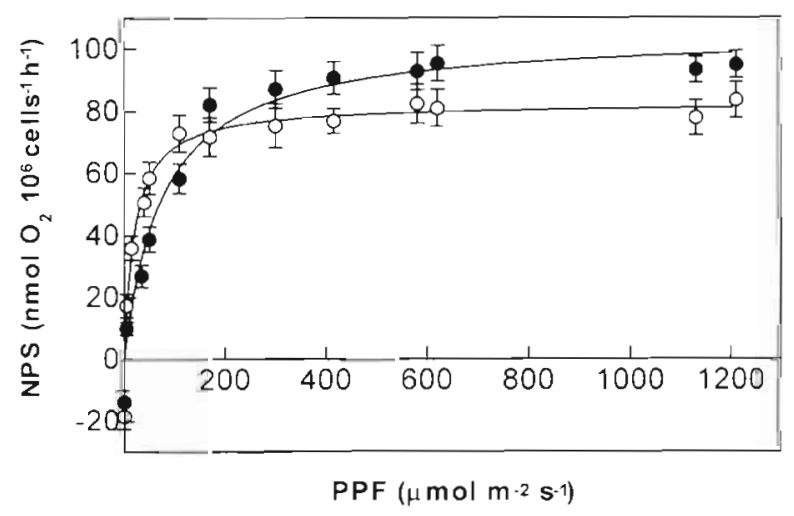

Fig. 1 Pleurochrysis sp. and P. elongata. Rates of net photosyntilesis iNPSj as a f́unciion oí protosynnetic photon ílux (PPF) for low calcifying ( $)$ cells and high-calcifying (O) cells Measurements were conducted at $15^{\circ} \mathrm{C}, \mathrm{pH} 7.5$ and $2.0 \mathrm{mM}$ $C_{1}$ (inorganic carbon). $(n=5 \pm S D)$ 
Table 1. Pleurochrysis sp. and P. elongata. Rates of net photosynthesis (NPS) in response to extracellular $\mathrm{O}_{2}$ concentration for low (LC) and high calcifying ( $\mathrm{HC}$ ) cells. Measurements were conducted at $15^{\circ} \mathrm{C}, 500 \mu \mathrm{mol} \mathrm{m} \mathrm{m}^{-2} \mathrm{~s}^{-1}$, pH 7.5 and $2.0 \mathrm{mM}$ $C_{1}$ (inorganic carbon). $(n=8 \pm S D)$

\begin{tabular}{|c|c|c|c|}
\hline$O_{2}(\mu M)$ & $\mathrm{O}_{2}$ in $\mathrm{Air}(\%)$ & \multicolumn{2}{|c|}{ NPS (nmol O $\left.10^{6} \mathrm{cell}^{-1} \mathrm{~h}^{-1}\right)$} \\
\hline $14.2-28.4$ & $1.3-2.6$ & $73.6 \pm 6.7$ & $65.8 \pm 4.9$ \\
\hline $198.6-255.4$ & $18.4-23.6$ & $60.1 \pm 5.8$ & $59.7 \pm 4.3$ \\
\hline $340.5-368.9$ & $31.5-34.1$ & $56.9 \pm 4.7$ & $57.4 \pm 3.5$ \\
\hline
\end{tabular}

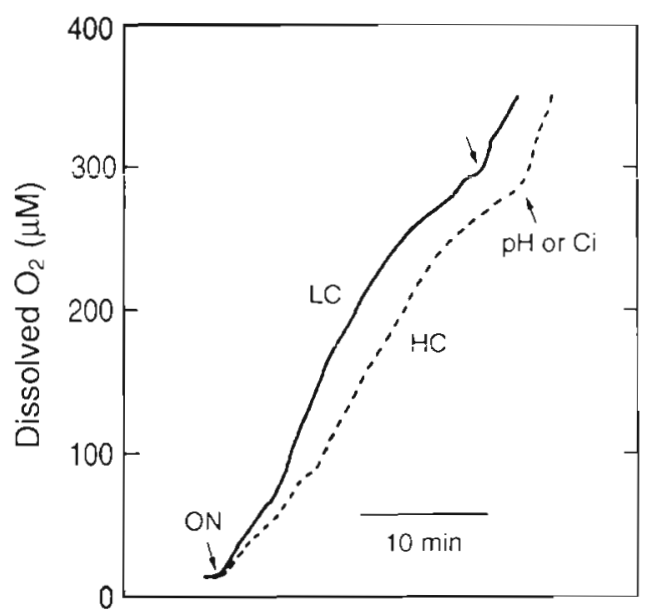

Fig. 2. Pleurochrysis sp. and $P$. elongata. Example of an $\mathrm{O}_{2}$ evolution trace (redrawn) for low calcifying (LC, solid line) and high calcifying ( $\mathrm{HC}$, dashed line) cells which were initially bubbled with $\mathrm{N}_{2}+\mathrm{CO}_{2}$ to reduce existing $\mathrm{O}_{2}$ levels to approximately $20 \mu \mathrm{M}$, and then illuminated (on) at pH 7.5 and $2.0 \mathrm{mM} \mathrm{C}_{1}$ (inorganic carbon). After $\mathrm{O}_{2}$ inhubition was apparent, the $\mathrm{CO}_{2}: \mathrm{O}_{2}$ ratio was increased by adjusting the $\mathrm{pH}$ to 6.0 (see Fig. 3), or by increasing the $\mathrm{C}_{1}$ concentration to $2 \mathrm{mM}_{\mathrm{B}}$ $\left(\mathrm{pH} / \mathrm{C}_{1}\right)$

increased to about $350 \mu \mathrm{M}$, rates of photosynthetic $\mathrm{O}_{2}$ evolution decreased, on average, by $23 \%(p<0.01)$ for LC cells and by $13 \%(p>0.05)$ for HC cells (Table 1$)$.

Photosynthetic $\mathrm{O}_{2}$ evolution became inhibited as $\mathrm{O}_{2}$ levels increased within the electrode chamber (Fig. 2, Table 1). For both LC cells and HC cells, rates of photosynthesis at $\geq 250 \mu \mathrm{M} \mathrm{O}_{2}$ could be enhanced to the rates more typically observed at $5 \% \mathrm{O}_{2}$ if the ambient $\mathrm{pH}$ was reduced to 6.0 , or if $\mathrm{C}_{\mathrm{i}}$ was added directly to the sample of photosynthesizing cells (Fig. 2).

Photosynthesis increased the ambient $\mathrm{pH}$. The $\mathrm{pH}$ of cell suspensions that had been illuminated for 20 min was increased by 1.0 unit for LC cells and by 0.5 units for $\mathrm{HC}$ cells, and then stabilized (Fig. 3). Upward drifts of extracellular $\mathrm{pH}$ were correlated with illumination since light withdrawal led to a rapid downward shift of $\mathrm{pH}_{\text {, }}$ and vice-versa. Moreover, the extracellular $\mathrm{pH}$ of $5 \mathrm{wk}$

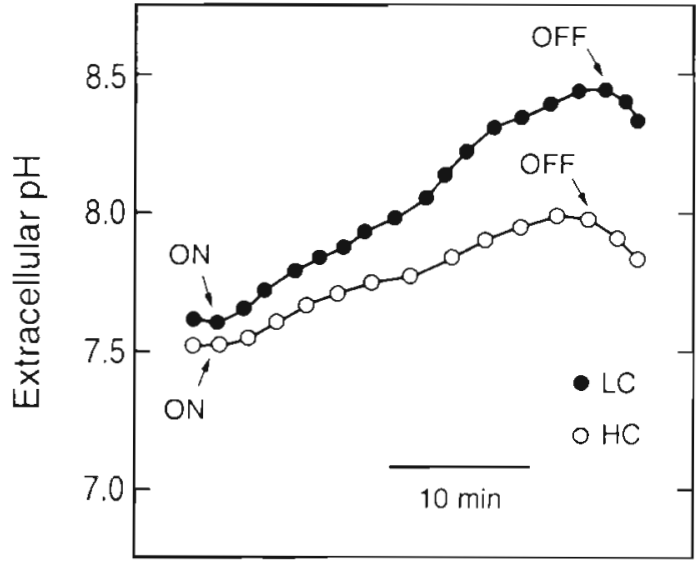

Fig. 3. Pleurochrysis sp. and P. elongata. Typical experiment showing extracellular $\mathrm{pH}$ changes during photosynthesis (on) or darkness (off) for low calcifying ( cells and high calcifying (O) cells. Measurements were conducted at $15^{\circ} \mathrm{C}$, $500 \mu$ moi $\mathrm{m}^{2} \mathrm{~s}$ ' and 2.0 mivi $\mathrm{C}_{1}$ (inorganic carbun)

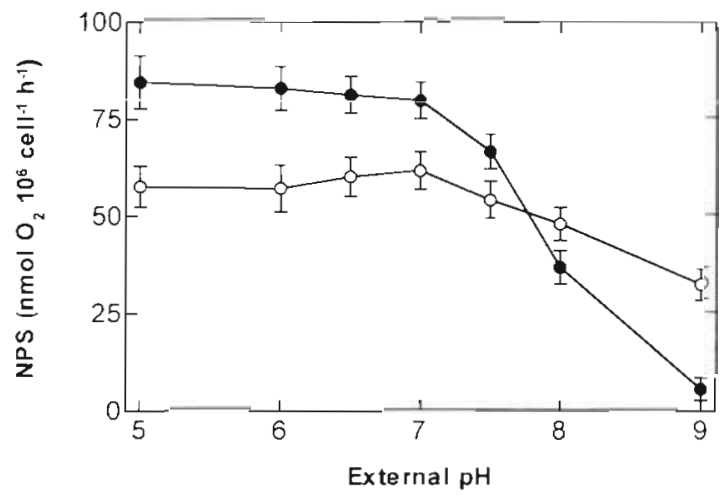

Fig. 4. Pleurochrysis sp. and $P$. elongata. Rates of net photosynthesis (NPS) as a function of ambient $\mathrm{pH}$ for low calcifying (-) cells and high calcifying (O) cells. Measurements were conducted at $15^{\circ} \mathrm{C}, 500 \mu \mathrm{mol} \mathrm{m} \mathrm{m}^{-2} \mathrm{~s}^{-1}$ and $2.0 \mathrm{mM} \mathrm{C}_{1}$ (inorganic carbon) $(n=7 \pm S D)$

old cultures in 21 flasks (after $6 \mathrm{~h}$ of illumination) averaged $8.9 \pm 0.2(n=4 \pm S D)$ and $8.2 \pm 0.3(n=5 \pm S D)$ for LC cells and HC cells, respectively. The photosynthetic $\mathrm{O}_{2}$ evolution of LC cells was stable from $\mathrm{pH} 5.0$ through $\mathrm{pH} 7.0$, decreased at $\mathrm{pH} 8.0$, on average, by $55 \%$ ( $\mathrm{p}<$ $0.01)$, and at $\mathrm{pH} 9.0$ averaged $7 \%(\mathrm{p}<0.01)$ of rates at pH 5.0 (Fig. 4). The photosynthetic $\mathrm{O}_{2}$ evolution of $\mathrm{HC}$ cells was similar from $\mathrm{pH} 5.0$ through $\mathrm{pH} 8.0$ and at pH 9.0 averaged $53 \%(p<0.01$ ) of rates at pH 5.0 (Fig. 4).

Acetazolamide $(2 \mathrm{mM})$ inhibited photosynthesis, on average, by $70 \%(p<0.01)$ for both $L C$ cells and $\mathrm{HC}$ cells (Fig. 5); however, the magnitude of the inhibition differed at lower $A Z$ concentrations. For example, inhibition by $0.25 \mathrm{mM} \mathrm{AZ}$ averaged $10 \%(\mathrm{p}<0.05)$ in $\mathrm{LC}$ cells and $30 \%(p<0.01)$ in $\mathrm{HC}$ cells (Fig. 5). Carbonic anhydrase activity of intact cells was 4 times greater for $\mathrm{HC}$ cells than for LC cells ( $\mathrm{p}<0.01$; Fig. 6). Inhibi- 


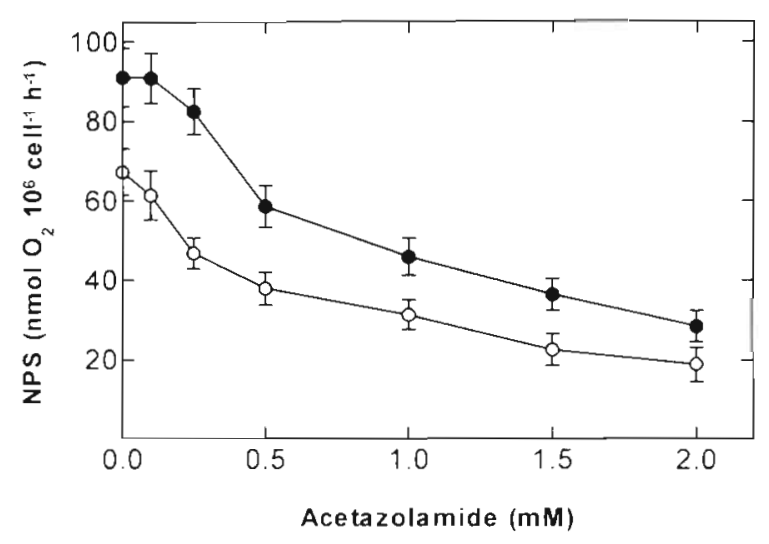

Fig. 5. Pleurochrysis sp. and $P$. elongata. Effect of acetazolamide on net photosynthesis (NPS) for low calcifying (•) cells and high calcifying (0) cells. Measurements were conducted at $15^{\circ} \mathrm{C}, 500 \mu \mathrm{mol} \mathrm{m} \mathrm{m}^{-2} \mathrm{~s}^{-1}$ and $2.0 \mathrm{mM} \mathrm{C}_{1}$ (inorganic carbon). $(\mathrm{n}=7 \pm \mathrm{SD})$

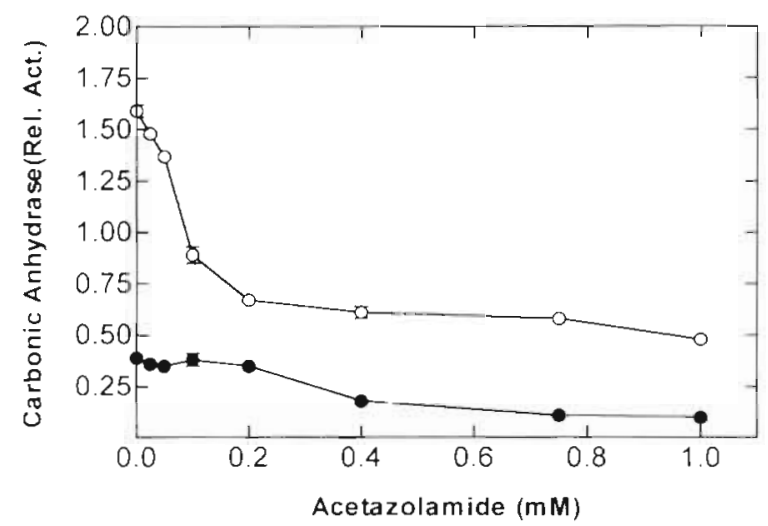

Fig. 6. Pleurochrysis sp. and P. elongata. Effect of acetazolamide on the activity of carbonic anhydrase (CA) for low calclfying (@) cells and high calcifying (O) cells. (CA activity is presented relative to a control consisting of $5 \mathrm{mM}$ TRIS-HCl buffer solution or boiled cell suspensions mixed with $\mathrm{CO}_{2}$ saturated distilled water.) $(n=7 \pm \mathrm{SD})$

tion of CA activity by $1.0 \mathrm{mM} \mathrm{AZ}$ averaged $74 \%$ for LC cells $(p<0.01)$ and $70 \%$ for HC cells ( $p<0.01)$, while at $0.2 \mathrm{mM} \mathrm{AZ}$ it averaged $9 \%(p<0.05)$ for LC cells and $58 \%(\mathrm{p}<0.01)$ for HC cells (Fig. 6)

The response of photosynthetic $\mathrm{O}_{2}$ evolution to increasing concentrations of external $\mathrm{C}_{1}$ is depicted in Fig. 7. The $\mathrm{CO}_{2}$ concentration required for a halfmaximal rate of photosynthetic $\mathrm{O}_{2}$ evolution, $\mathrm{K}_{0.5}\left(\mathrm{CO}_{2}\right)$, calculated from double-reciprocal plots of net photosynthesis at $\mathrm{pH} 5.0$ was 37 and $51 \mu \mathrm{M}$ for $\mathrm{LC}$ and $\mathrm{HC}$ cells, respectively (Fig. $7 \mathrm{~A}$ ). The $\mathrm{C}_{\mathrm{i}}$ concentration required for a half-maximal rate of photosynthetic $\mathrm{O}_{2}$ evolution, $K_{0.5}\left(\mathrm{C}_{1}\right)$, obtained from double-reciprocal plots of net photosynthesis at $\mathrm{pH} 7.5$ was 0.58 and 0.21 mivi for LC and $\bar{H}$ C cells, respectively (Fig. 7B), while $K_{0 .}\left(\mathrm{C}_{1}\right)$ at $\mathrm{pH} 8.5$ was 1.25 and $0.55 \mathrm{mM}$ for $\mathrm{LC}$ and $\mathrm{HC}$ cells, respectively (Fig. $7 \mathrm{C}$ ).

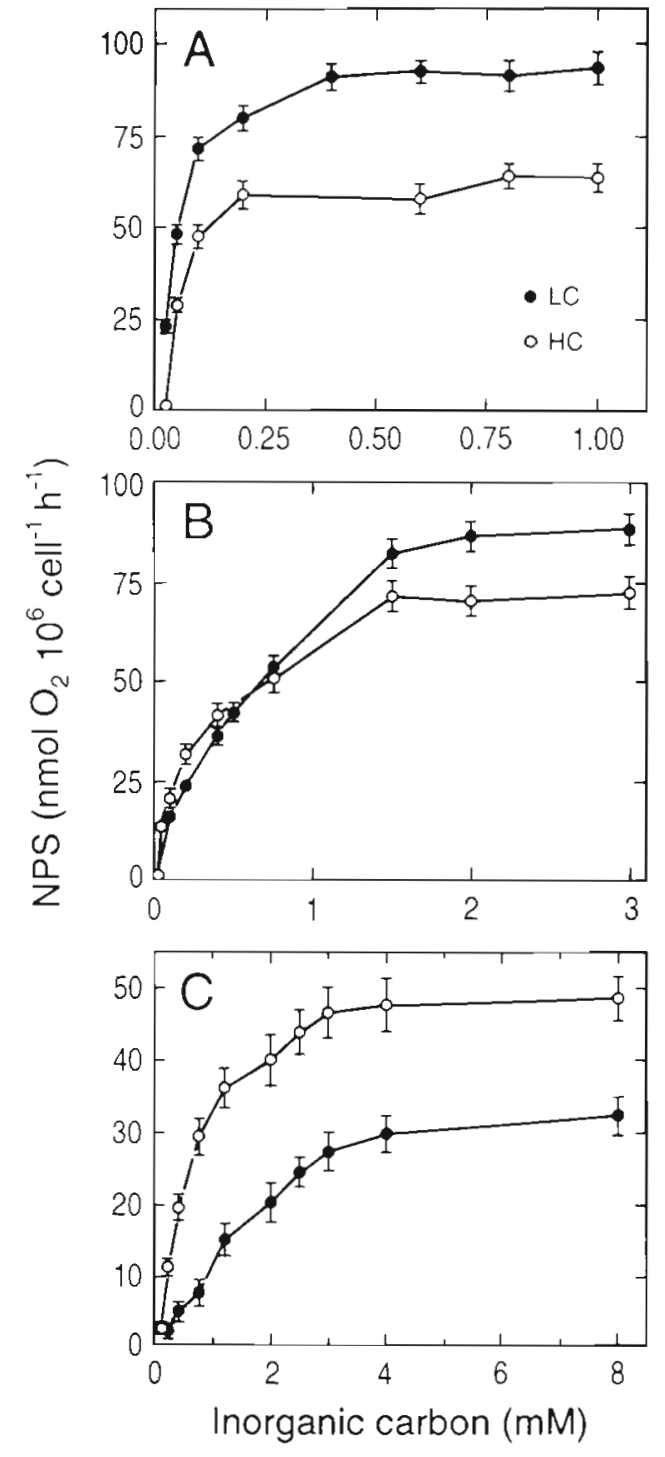

Fig. 7. Pleurochrysis sp. and $P$. elongata. Effect of $C_{1}$ (inorganic carbon) concentration on net photosynthesis (NPS) for low calcifying (๑) cells and high calcifying (O) cells at pH 5.5 (A), $7.5(\mathrm{~B})$, and $8.5(\mathrm{C})$. Measurements were conducted at $15^{\circ} \mathrm{C}$ and $500 \mu \mathrm{mol} \mathrm{m} \mathrm{m}^{-2} \mathrm{~s}^{-1}$. (n= 4 or $\left.5 \pm \mathrm{SD}\right)$

Table 2. Pleurochrysis sp. and P. elongata. The effect of photosynthetic photon flux (PPF) on rates of calcium uptake for low calcifying (LC) cells and high calcifying (HC) cells. Measurements were conducted at $15^{\circ} \mathrm{C}, \mathrm{pH} 7.5$ and $2.0 \mathrm{mM} \mathrm{C}_{1}$ (inorganic carbon). $(n=7 \pm S D$ )

\begin{tabular}{|crr|}
\hline PPF & \multicolumn{2}{c|}{ Calcium uptake } \\
$\left(\mu \mathrm{mol} \mathrm{m}{ }^{-2} \mathrm{~s}^{-1}\right)$ & (nmol Ca $\left.\mathrm{C}^{2+} 10^{6} \mathrm{cells}^{-1} \mathrm{~h}^{-1}\right)$ \\
& $\mathrm{HC}$ & $\mathrm{HC}$ \\
\hline 500 & $9.2 \pm 2.9$ & $2 \bar{f} . \overline{7} \pm 3.3$ \\
75 & $10.9 \pm 2.1$ & $24.2 \pm 3.1$ \\
Dark & $1.2 \pm 0.7$ & $5.1 \pm 1.3$ \\
\hline
\end{tabular}


Table 3. Non-enzymatic production of $\mathrm{CO}_{2}$ from $100 \mu \mathrm{M}$ $\mathrm{HCO}_{3}$ dissolved in seawater at $15^{\circ} \mathrm{C}\left(d \mathrm{CO}_{2} / d \mathrm{t} ; \mu \mathrm{mol} \mathrm{CO} \mathrm{CO}_{2} \mathrm{ml}\right.$ $\left.\mathrm{h}^{-1}\right)$ and net photosynthetic rates (NPS; $\mu \mathrm{mol} \mathrm{O} \mathrm{ml} \mathrm{cell}^{-1} \mathrm{~h}^{-1}$ ) measured with $0.25 \mathrm{mM}$ acetazolamide at various external $\mathrm{pH}$ for low calcifying (LC) cells and high calcifying (HC) cells of Pleurochrysis. The first set of calculations of $\mathrm{dCO}_{2} / d t$ (Johnson 1982 , Eq. 6) assumes that photosynthesizing cells remove all $\mathrm{CO}_{2}$ as rapidly as it is formed from dehydration of $\mathrm{HCO}_{3}{ }^{-}$, thus $\mathrm{CO}_{2}$ tends to zero. The second set of calculations assumes that cells maintain a $\mathrm{CO}_{2}$ compensation point of approximately $1 \mu \mathrm{M}$. $(n=5 \pm S D)$

\begin{tabular}{|lcrrr|}
\hline & \multicolumn{4}{c}{$\mathrm{pH}$} \\
& 6.0 & 7.5 & 8.0 & \multicolumn{1}{c|}{9.0} \\
\hline$d \mathrm{CO}_{2} / d \mathrm{t}\left(\right.$ zero $\left.\mathrm{CO}_{2}\right)$ & 1.901 & 0.064 & 0.024 & 0.006 \\
$\mathrm{dCO} / \mathrm{dt}\left(1 \mu \mathrm{M} \mathrm{CO} \mathrm{CO}_{2}\right)$ & 1.883 & 0.049 & 0.006 & -0.039 \\
$\mathrm{NPS}-\mathrm{LC}$ & 0.071 & 0.014 & 0.017 & 0.009 \\
$\mathrm{NPS}-\mathrm{HC}$ & 0.048 & 0.021 & 0.025 & 0.020 \\
\hline
\end{tabular}

Rates of calcium uptake for HC cells averaged $200 \%$ higher $(\mathrm{p}<0.01)$ at saturating PPF and $122 \%$ higher $(p<0.01)$ at subsaturating PPF than rates of calcium uptake for LC cells (Table 2). Calcium uptake in the dark was $325 \%$ higher $(p<0.01)$ in HC cells than in LC cells and averaged 13 and $24 \%$ of the calcium uptake rates of illuminated LC cells and $\mathrm{HC}$ cells, respectively (Table 2 ).

Comparisons between photosynthetic rates and the $\mathrm{CO}_{2}$ supplied from non-enzymatic dehydration rates of $\mathrm{HCO}_{3}{ }^{-}(100 \mu \mathrm{M})$ showed that the latter was sufficient to account for observed photosynthesis of both types of cell at $\mathrm{pH} 6.0$ and $\mathrm{pH} 7.5(\mathrm{p}<0.01$; Table 3). Relative concentrations of $\mathrm{CO}_{2}$ and $\mathrm{HCO}_{3}{ }^{-}$vary with $\mathrm{pH}$, and rates of $\mathrm{CO}_{2}$ formation will depend on the compensation concentration of $\mathrm{CO}_{2}$ maintained by the cells in the experimental setup. At $\mathrm{pH} 8.0$ and assuming zero $\mathrm{CO}_{2}$, utilization rates of $\mathrm{CO}_{2}$ during photosynthesis in both $\mathrm{HC}$ and $\mathrm{LC}$ cells were within the range of the $\mathrm{CO}_{2}$ being produced spontaneously from $\mathrm{HCO}_{3}{ }^{-}(p>0.05)$, while at $1 \mu \mathrm{M}$, photosynthetic $\mathrm{CO}_{2}$ uptake was substantially higher than $\mathrm{CO}_{2}$ formation at that $\mathrm{pH}(\mathrm{p}<$ 0.01 ; Table 3). At pH 9.0 rates of non-enzymatic $\mathrm{CO}_{2}$ production were not sufficient to support the rates of photosynthesis observed for both LC and HC cells ( $p<$ 0.01; Table 3).

\section{DISCUSSION}

The PPF at which photosynthetic rates of $\mathrm{LC}$ and $\mathrm{HC}$ cells were maximal exceeded the PPF available to the cultures during cell growth (about $75 \mu \mathrm{mol} \mathrm{m}^{-2} \mathrm{~s}^{-1}$ ), and photoinhibition was not observed in either strain at a PPF as high as $1000 \mu \mathrm{mol} \mathrm{m} \mathrm{m}^{-2} \mathrm{~s}^{-1}$. The higher initial rates (see Fig. 1) observed for $\mathrm{HC}$ cells at low PPF sug- gest that Pleurochrysis sp. has a decided advantage for growth, even though the content of chlorophyll a was lower than that in LC cells of $P$. elongata. The range of light intensities tolerated by these strains enables them to withstand a wide range of environmental light conditions; similar light tolerance characteristics have been found for several other microalgal species.

Since the intracellular concentration of oxygen produced during photosynthesis can reach levels far above normal atmospheric levels, the inhibition of photosynthesis observed at high $\mathrm{O}_{2}$ was most likely the result of competition of substrates, $\mathrm{CO}_{2}$ versus $\mathrm{O}_{2}$, for the active site of the carboxylating/oxygenating enzyme, Rubisco. When aliquots of $C_{1}$ were added to the cell suspensions at approximately $280 \mu \mathrm{M} \mathrm{O}_{2}$, a sharp increase in the photosynthetic $\mathrm{O}_{2}$ evolution was observed. $\mathrm{O}_{2}$ evolution could also be re-established by acidifying the medium with $\mathrm{HCl}$ or by reducing $\mathrm{O}_{2}$ levels back to $20 \mu \mathrm{M}$ thus modifying the $\mathrm{CO}_{2}: \mathrm{O}_{2}$ ratios in the measuring chamber.

Inorganic carbon at $\mathrm{pH} 9.0$ is mainly $\mathrm{CO}_{3}{ }^{2-}$ with less $\mathrm{HCO}_{3}{ }^{-}$and much less $\mathrm{CO}_{2}$. In particular, a fixed amount of $\mathrm{C}_{\mathrm{i}}$ at $\mathrm{pH} 9.0$ and $15^{\circ} \mathrm{C}$ maintained in a closed system will contain about $1 \% \mathrm{CO}_{2}$ and $47 \% \mathrm{HCO}_{3}^{-}$, whereas at $\mathrm{pH} 5.0$ about $90 \%$ will consist of $\mathrm{CO}_{2}$ and only $6 \%$ will be $\mathrm{HCO}_{3}^{-}$The photosynthetic activity measured at a range of external $\mathrm{pH}$ indicates that $\mathrm{HC}$ cells utilize $\mathrm{HCO}_{3}{ }^{-}$more efficiently than LC cells, with $\mathrm{LC}$ cells relying more exclusively on a $\mathrm{CO}_{2}$ supply. The $\mathrm{C}_{1}$ preference shown by Pleurochrysis is similar to that reported for Emiliania huxleyi (Nimer et al. 1992, Nimer \& Merrett 1993). Even though both strains of Pleurochrysis benefit from enhanced $\mathrm{CO}_{2}$ availability at low ambient $\mathrm{pH}$, LC cells were still capable of maintaining minimal photosynthesis at alkaline $\mathrm{pH}$ where $\mathrm{CO}_{2}$ concentration is low.

The slight alkalinization of the external medium during photosynthesis is, in Pleurochrysis, comparable to that reported for high calcifying cultures of Emiliania huxleyi (Nimer et al. 1992, Dong et al. 1993). These results are also comparable to findings on several microalgae which have $\mathrm{CO}_{2}$-concentrating systems (Shiraiwa et al. 1993) that maintain pH balances intracellularly and generally increase $\mathrm{pH}$ extracellularly. However, in the case of Pleurochrysis and probably other coccolithophorids, the extent of external alkalinization is reduced because protons are produced as part of the $\mathrm{CaCO}_{3}$ deposition during photosynthesis. This effect reduces alkalinity of the cytosol and favors release of $\mathrm{CO}_{2}$ from $\mathrm{HCO}_{3}{ }^{-}$which further increases the availability of substrate for photosynthesis (Raven 1991, McConnaughey 1994). Conversely, the fact that alkalinization of the medium of the LC cells was more pronounced may reflect the lower calcification and 
lower production of protons from the acidotic reaction. Thus, in the absence of calcification, the consequent alkalinization of the cytosol may be countered by expulsion of $\mathrm{OH}^{-}$from the cell or, alternatively, recruitment of $\mathrm{H}^{+}$from the medium.

In contrast to the response found in $\mathrm{HC}$ cells of Pleurochrysis $\mathrm{sp}$. at $\mathrm{pH} 8.5$ where photosynthesis reached saturation at $2.2 \mathrm{mM} \mathrm{C}_{1}$, photosynthesis in LC cells was not carbon saturated at the $C_{i}$ levels of seawater (2.1 $\mathrm{mM}$ ); this is consistent with previous results for airgrown, LC cells of a strain of Emiliania huxleyi (Nimer et al. 1992, Nimer \& Merrett 1993). Furthermore, $K_{0.5}\left(\mathrm{CO}_{2}\right)$ averaged $44 \mu \mathrm{M}$ for Pleurochrysis reflecting a low affinity for $\mathrm{CO}_{2}$. This low affinity was comparable to that of a HC strain of E. huxleyi, which had a $K_{0.5}\left(\mathrm{CO}_{2}\right)$ of $55 \mu \mathrm{M}$ (Sekino \& Shiraiwa 1994). These values are higher than the $\mathrm{CO}_{2}$ concentration of seawater (ca $15 \mu \mathrm{M}$ ) suggesting $\mathrm{HCO}_{3}{ }^{-}$utilization to yield $\mathrm{CO}_{2}$ intra- and/or extracellularly. In another study Nimer \& Merrett (1992) reported a $K_{0.5}\left(\mathrm{CO}_{2}\right)$ (measured by $\mathrm{C}_{\mathrm{i}}$ uptake at $\mathrm{pH}$ 5.0) of $115 \mu \mathrm{M}$ for a $\mathrm{HC} E$. huxleyi and $12.5 \mu \mathrm{M}$ for a LC strain. Similar affinities for $\mathrm{CO}_{2}$ have been found for other unicellular algae, e.g. a $K_{0.5}\left(\mathrm{CO}_{2}\right)$ of $57 \mu \mathrm{M}$ at $\mathrm{pH} 8.0$ was measured for Phaeodactylum tricornutum (Patel \& Merrett 1986) and $50 \mu \mathrm{M}$ at $\mathrm{pH} 8.0$ for Porphiridium purpureum (Dixon et al. 1987), both having $\mathrm{CO}_{2}$-concentrating systems but lacking calcification.

The effect of $A Z$ on CA activity in intact cells can be regarded as inhibition of periplasmic CA (Moroney et al. 1985), although there are indications that some internal CA may also be inhibited (Palmquist et al. 1990). Photosynthesis in Pleurochrysis was inhibited by $\mathrm{AZ}$ to a similar extent for both cell types at concentrations an order of magnitude higher than those used in other studies (Palmqvist et al. 1994), but the inhibition was less for LC cells at low AZ concentrations, indicating that for $\mathrm{HC}$ cells $\mathrm{C}_{1}$ fixation relies on extracellular, $\mathrm{CA}$ mediated conversions of $\mathrm{HCO}_{3}^{-}$. Fractions of cell homogenates of Pleurochrysis lacked CA activity, except for a chloroplastic CA (Quiroga \& González 1993) that may likely act to maintain $\mathrm{CO}_{2}$ levels at the site of Rubisco (Nimer et al. 1994). Additionally, CA was absent in cell homogenates or intact cells of Emiliania huxleyi (Sekino \& Shiraiwa 1994), but significant CA activity appeared in the chloroplast of cells in stationary phase (Nimer et al. 1994).

Results from this study indicate that $\mathrm{CO}_{2}$ produced from non-enzymatic dehydration of $100 \mu \mathrm{M} \mathrm{HCO}_{3}^{-}$ greatly exceeded rates of photosynthesis at acidic $\mathrm{pH}$. At $\mathrm{pH} 8.0$ rates of $\mathrm{CO}_{2}$ production from $100 \mu \mathrm{M} \mathrm{HCO}_{3}^{-}$ were still greater than rates of photosynthesis for LC cells at a zero $\mathrm{CO}_{2}$ compensation concentration. At $\mathrm{pH} \mathrm{9.0,} \mathrm{the} \mathrm{dehydration} \mathrm{rates} \mathrm{approximate,} \mathrm{or} \mathrm{are}$ lower than, those of photosynthesis, supporting the notion that $\mathrm{HCO}_{3}{ }^{-}$is the substrate at the plasmalemma. Periplasmic dehydration of $\mathrm{HCO}_{3}{ }^{-}$is suggested by the presence of CA but whether it is a (non)charged species that is translocated across the membrane, or whether protons are recruited from intra- or extracellular sources, is unknown at this time.

Calcium uptake in Pleurochrysis probably reflects the production of coccoliths but is not a direct measure of calcification. It occurred under conditions of illumination as well as in darkness, as was demonstrated for Pleurochrysis carterae whose rates of calcification were similar in both light and dark conditions (van der Wal et al. 1987). In the present study, light to dark calcification ratios in Pleurochrysis were about 2, below the average $(>10)$ for most calcareous algae (McConnaughey 1994). An equimolar ratio of calcification to photosynthesis suggests a push-and-pull mechanism. The unavaidable rise in alkalinity in the cytosol when $1 \mathrm{M} \mathrm{HCO}_{3}{ }^{-}$is converted to $\mathrm{CO}_{2}$ is counterbalanced by protons released from $1 \mathrm{M} \mathrm{HCO}_{3}^{-}$during calcite formation in the calcifying vesicle. This push-and-pull mechanism is of significant advantage where $\mathrm{HCO}_{3}{ }^{-}$is the dominant form of extracellular $\mathrm{C}_{1}$ and under conditions where a steep cytosolic to extracellular $\mathrm{pH}$ gradient exists (Dong et al. 1993, Nimer \& Merrett 1993).

In summary, this study suggests that in Pleurochrysis, $\mathrm{CO}_{2}$ is the principal substrate for photosynthesis in LC cells, and that $\mathrm{HC}$ cells can additionally utilize $\mathrm{HCO}_{3}{ }^{-}$. Thus, the alkaline seawater environment potentially places constraints on the cell in terms of $\mathrm{CO}_{2}$ availability for photosynthesis. This constraint can be overcome by the $\mathrm{HC}$ cells because protons liberated during calcification facilitate the movement of $\mathrm{HCO}_{3}^{-}$ into the cell and release of $\mathrm{CO}_{2}$ for photosynthesis. Low affinities for $\mathrm{CO}_{2}$ in both strains require increased internal $\mathrm{CO}_{2}$ concentrations to support photosynthesis, which could be achieved via a $\mathrm{CO}_{2}$-concentrating system at the plasmalemma or, more likely, through generation of $\mathrm{CO}_{2}$ (from $\mathrm{HCO}_{3}^{-}$) in the chloroplast and concurrent production of calcite (during coccolith formation) in the intracellular coccolith vesicle.

Acknowledgements. We thank Drs R. S. Alberte and R. Zimmerman for inviting us to use their laboratory facilities and for advice on the calcium measurements. The technical assistance of Mrs Diana Steller and Mr Marco Vasquez is appreciated. We also thank Prof. George Laties for reading the manuscript and the Office of Naval Research for funding.

\section{LITERATURE CITED}

Badger MR (1985) The fluxes of inorganic carbon species during pinotosynthesis in cyanobacteria with particuiar reierence to Synechococcus sp. In: Lucas WJ, Berry J (eds) Inorganic carbon uptake by aquatic photosynthetic organisms. Am Soc Plant Physiol, Rockville, MD, p 39-52 
Badger MR, Kaplan A, Berry JA (1980) Internal inorganic carbon pool of Chlamydomonas reinhardti: evidence for a carhon dioxide concentrating mechanism. Plant Physiol $66: 407-413$

Beer S (1994) Mechanisms of inorganic carbon acquisition in marine macroalgae (with special reference to the chlorophyta). In: Chapman DJ, Round F (eds) Progress in phycological research. Biopress Ltd, Bristol, England, p 179-207

Brown RM, Romanovicz DK (1976) Biogenesis and structure of Golgi-derived cellulosic scales in Pleurochrysis. I. Role of the endomembrane system in scale assembly and exocytosis. Appl Polym Symp 28:537-585

Dixon GK, Patel BN, Merrett MJ (1987) Role of intracellular carbonic anhydrase in inorganic-carbon assimilation by Porphiridium purpureum. Planta 172:508-513

Dong LF, Nimer NA, Okus E, Merrett MJ (1993) Dissolved inorganic carbon utilization in relation to calcite production in Emiliania huxleyi (Lohmann) Kamptner. New Phytol 123:679-684

Johnson KS (1982) Carbon dioxide hydration and dehydration kinetics in seawater. Limnol Oceanogr 27:549-585

Kwon DK, González EL (1994) Localization of $\mathrm{Ca}^{2+}$-stimulated ATPase in the coccolith-producing compartment of cells of Pleurochrysis sp. (Prymnesiophyceae). J Phycol 30: $689-695$

McConnaughey TA (1994) Calcification, photosynthesis, and global carbon cycles. In: Doumenge E, Allemand D, Toulemont A (eds) Past and present biommeralization processes. Consideration about the carbonate cycle IUCNCOE Workshop Monaco, Nov 1993. Bulletin de l'Institut Oceanographique, Monaco, no. 13, p 137-156

Moran R (1982) Formulae for determination of chlorophyllous pigments extracted with $\mathrm{N}, \mathrm{N}$-dimethylformamide. Plant Physiol 69:1376-1381

Moroney JV, Husic HD, Tolbert NE (1985) Effect of carbonic anhydrase inhibitors on inorganic carbon accumulation by Chlamydomonas reinhardtii. Plant Physiol 79:177-183

Munoz J, Merrett MJ (1989) Inorganic-carbon transport in some marine eukaryotic microalgae. Planta 178:450-455

Nimer NA, Dixon GK, Merrett MJ (1992) Utilization of inorganic carbon by the coccolithophorid Emiliania huxleyi (Lohmann) Kamptner. New Phytol 120:153-158

Nimer NA, Guan Q, Merrett MJ (1994) Extra- and intracellular carbonic anhydrase in relation to culture age in a high-calcifying strain of Emiliania huxleyi Lohmann. New Phytol 126:601-607

This article was submitted to the editor
Nimer NA, Merrett MJ (1992) Calcification and utulization of inorganic carbon by the coccolithophorid Emiliania huxleyl Lohmann. New Phytol 12:173-177

Nimer NA, Merrett MJ (1993) Calcification rate in Emiliania huxleyi Lohmann in response to light, nitrate and availability of inorganic carbon. New Phytol 123:673-677

Palmqvist K, Ramazanov Z, Samuelson G (1990) The role of extracellular carbonic anhydrase for accumulation of inorganic carbon in the green algae Chlamydomonas reinhardtii. A comparison between wild-type and cell-wallless mutant cells. Physiol Plant 80:267-276

Palmquist K, Yu JW, Badger MR (1994) Carbonic anhydrase activity and inorganic carbon fluxes in low- and high- $\mathrm{C}_{1}$ cells of Chlamydomonas reinhardtii and Scenedesmus obliquus. Physiol Plant 90:537-547

Patel BN, Merrett MJ (1986) Inorganic carbon uptake by the marine diatom Phaeodactylum tricornutum. Planta 169: $222-227$

Pethig R, Kuhn M, Payne $\mathrm{R}_{\text {, Adler }} \mathrm{E}_{1}$ Chen TH, Jaffe LF (1989) On the dissociation constants of BAPTA-type calcium buffers. Cell Calcium 10:491-498

Quiroga O, González. EL (1993) Carbonic anhydrase in the chloroplast of a coccolithophorid (Prymnesiophyceae). J Phycol 29:321-324

Raven JA (1991) Implications of inorganic carbon utilization: ecology, evolution, and geochemistry. Can $J$ Bot 69: 908-924

Sekino K, Shuraiwa Y (1994) Accumulation and utlization of dissolved inorganic carbon by a marine unicellular coccolithophorid, Emiliania huxleyi. Plant Cell Physiol 35: 353-361

Shiraiwa Y, Goyal A, Tolbert NE (1993) Alkalinization of the medium by unicellular green algae during uptake of dissolved inorganic carbon. Plant Cell Physiol 34:649-657

Sikes CS, Roer RD, Wilbur KM (1980) Photosynthesis and coccolith formation: inorganic carbon sources and net inorganic reaction of deposition. Limnol Oceanogr 25:248-261

Sikes CS. Wheeler AP (1982) Carbonic anhydrase and carbon fixation in coccolithophorids. J Phycol 18:423-426

van der Wal P, de Vrind JPM, de Vrind-de Jong EW, Borman $\mathrm{AH}$ (1987) Incompleteness of the coccosphere as a possible stimulus for coccolith formation in Pleurochrysis carterae (Prymnesiophyceae). J Phycol 23:218-221

Wainwright IM, Kwon DW, González E (1992) Isolation and characterization of Golgi from Coccolithus pelagicus (Prymnesiophyceae). J Phycol 28:643-648

Manuscript first received: August 31, 1995

Revised version accepted: January 9, 1996 